\title{
Theoretical models of synaptic short term plasticity
}

\section{Matthias H. Hennig *}

School of Informatics, Institute for Adaptive and Neural Computation, University of Edinburgh, Edinburgh, UK

${ }^{*}$ Correspondence: m.hennig@ed.ac.uk

Edited by:

Si Wu, Beijing Normal University, China

Keywords: short term plasticity, Synaptic Transmission, mathematical model, synaptic depression, synaptic facilitation

\section{A commentary on}

Theoretical models of synaptic short term plasticity

by Matthias H. Hennig. (2013). Front. Comput. Neurosci. 7:45. doi: 10.3389/ fncom.2013.00045

There is a misprint in Equation 11, which should read:

$$
C V=\sqrt{\frac{1-p(t)}{N(t) p(t)}}
$$

\section{ACKNOWLEDGMENTS}

Many thanks to Rui P. Costa for pointing out this mistake.

Received: 14 October 2013; accepted: 15 October 2013; published online: 30 October 2013.

Citation: Hennig MH (2013) Theoretical models of synaptic short term plasticity. Front. Comput. Neurosci. 7:154. doi: 10.3389/fncom.2013.00154
This article was submitted to the journal Frontiers in Computational Neuroscience.

Copyright (c) 2013 Hennig. This is an open-access article distributed under the terms of the Creative Commons Attribution License (CC BY). The use, distribution or reproduction in other forums is permitted, provided the original author(s) or licensor are credited and that the original publication in this journal is cited, in accordance with accepted academic practice. No use, distribution or reproduction is permitted which does not comply with these terms. 